\title{
Effect of Ethical Leadership and Leader-Member Exchange on Voice Behavior - Moderating Impact of Empowerment
}

\author{
Ling Yuan ${ }^{1} \quad$ Manh-Cuong $\mathrm{Vu}^{1 *} \quad$ Thi-Trang-Nhung Nguyen ${ }^{1,2}$ \\ 1. Business School, Hunan University, Changsha 410082, Hunan, China \\ 2. Department of business administration, Hanoi University of Industry, Hanoi, Vietnam
}

\begin{abstract}
The purpose of this paper is to examine the effect of ethical leadership and leader-member exchange on employee voice behavior and moderating effect of employee empowerment. Data collected from 718 full time working employees via questionnaires, incorporating ethical leadership, leader-member exchange, employee voice behavior and employee empowerment. Correlation and regression analysis was to examine the relationship, association and effect of the variables on each other. Results indicated a strong, positive and significant association between ethical leadership, leader-member exchange and employee empowerment and employee voice behavior. Further regression results specify that ethical leadership, leader-member exchange and employee empowerment effect employee voice behavior positively and significantly. Results point out that interactive effect of employee empowerment is there in between leader-member exchange and employee voice behavior. Current study provides a new aspect to focus for the organizations that is importance of ethical leadership to enhance employee voice behavior through leader-member exchange and employee empowerment. Organization needs to acknowledge the significance of ethical leadership behavior to training and enhancing ethical behavior of leader in order to maximize employee voice behavior for organization efficiency.
\end{abstract}

Keywords: Ethical leadership;leader-member exchange; Employee voice behavior; Employee empowerment;

DOI: $10.7176 / \mathrm{EJBM} / 11-9-15$

Publication date:March $31^{\text {st }} 2019$

\section{Introduction}

Leader or leadership plays an important role on management. It has occupied the attention of both theorists and practitioners alike. Recently, it is considered significant in ethical issues with the various ethical scandals which have come out in open. Brown, Treviño, \& Harrison, (2005a) have also addressed this topic through exploring the concept of ethical leadership and its impact on the behavior of employees. However, although the research on ethical leadership is important, it is still limited. This problem can lie in the difficulties related with researching ethical leadership in a field setting. This study uses an experimental design to explore the impact of ethical leadership and leader-member exchange on employee voice behavior under moderating impact of employee empowerment.

According to (Walumbwa et al. 2011), there were many different impact processes that including in ethical leadership. These processes include leader-member exchange Treviño, Weaver, and Reynolds, (2006), empowerment (Hassan, Mahsud, Yukl, \& Prussia, 2013), task performance (Piccolo Ronald F., Greenbaum Rebecca, Hartog Deanne N. den, \& Folger Robert, 2010). Although, various researchers have illuminate the impact of ethical leadership on employee behavior, few scholars has studied the immediate and mediate relationship between ethical leadership behavior and subordinate voice behavior. Moreover, relatively few studies have tested the complex effect of mediator and moderator on this relationship.

Therefore, the present study tests the process that ethical leadership influences employee voice behavior by developing two types of mechanisms and testing the relationship between both mediator and moderator to enhance our understanding of the complex relationship between ethical leadership and voice behavior. We propose that the effect of ethical leadership on subordinate voice behavior is realized through two mechanisms: the mediating role of leader-member exchange and the moderating role of employee empowerment.

This study examined the effect of ethical leadership on employee voice behavior at service companies in Vietnam. The service sector was chosen because of its sustainable growth in the last decade. Vietnamese service companies have performed remarkably well in mobilizing the growth and development of the economy by contributing to high rate of the total exports and the industrial output. Service companies also made a significant contribution toward Vietnam`s GDP.

Against this backdrop, the present study has forwarded an integrated model that tests the role of ethical leadership in promoting employee voice behavior and mediated through leader-member exchange. It also examines the moderating role of employee empowerment in influencing the relationship between leader-member exchange and employee voice behavior. Therefore, this study contributes to the literature on ethical leadership, leadermember exchange, employee voice behavior and employee empowerment by clarifying and highlighting the importance of ethical leadership in promoting employee voice behavior by promoting the relationship between leader and member. 


\section{Theoretical background and hypotheses}

\subsection{Ethical leadership and leader-member exchange}

According to Brown, Treviño, \& Harrison, (2005b), the concept of ethical leadership is defined as "the demonstration of normatively appropriate conduct through personal actions and interpersonal relationships, and the promotion of such conduct to followers through two-way communication, reinforcement, and decision-making" (Brown et al., 2005b). The ethical behavior of leaders play an important role in enhancing follower attitudes and behaviors (Brown et al., 2005b). Moreover, leader-member exchange is also defined by (Graen \& Scandura, 1987) as the quality of exchange between a leader and an employee. These exchanges are posited to fall along a continuum. Leader-member exchange theory is always received deeply attention in researching the organizational sciences (Nahrgang, Morgeson, \& Ilies, 2009). Leader-member exchange is based on the degree of emotional support and exchange of valued resources between an employee and his or her immediate supervisor (Walumbwa et al., 2011).

Ethical leaders can promote to enhance high quality exchange between leader and their employees through a number of ways. Firstly, ethical leaders are moral persons who are trustworthy and honest. They like as principled decision makers who care more about the greater good of employees, organization and society (Brown \& Treviño, 2006). Secondly, followers feel that leaders are committed to them when they perceive that leaders make in their best interests and are caring. As a result, ethical leaders enhance high-quality leader-member exchange. Therefore, we expected that there is a positive relationship between ethical leadership and leader-member exchange H1. There will be a significant and positive relationship between ethical leadership and leader-member exchange

\subsection{Leader-member exchange as a mediator between ethical leadership and employee voice behavior} According to Brown \& Treviño, (2006), the social exchange theory (Blau, 1964) and the social learning theory (Bandura \& Walters, 1977) provide theoretical elucidation for ethical leadership - follower behaviors link. Brown et al. (2005b) stated that employees of ethical leaders are likely to perceive themselves as being in a social exchange link with their leaders because they receive the ethical treatment and feel the trust. When followers feel that they are cared and best interested at heart by their leaders, they are likely to reciprocate by improving their voice behavior. Thus we suggest that ethical leaders are likely to influence employee voice behavior by enhancing the quality of exchange between leaders and employees. And we argue that the reason why ethical leadership predicts employee voice behavior is that ethical leadership behavior enhances high-quality leader-member exchange. In turn, high-quality leader-member exchange improves employee voice behavior.

The concept of voice is defined by a number of scholars. According to Hirschman, (1970), voice is "any attempt at all to change rather than to escape from an objectionable state of affairs" (p.70). Thibaut \& Walker, (1975) defined voice as an opportunity to present one`s opinions to decision-makers. Voice is one type of extrarole behavior that pointing out problems and suggesting for doing things better.

Prior researches has found that there are an existing the positive relationship between leader member exchange and employee voice. Followers that has relatively higher relationship with their supervisors may feel obliged to reciprocate to their supervisor through engaging in more extra-role behavior to fulfill the reciprocity obligations (Gerstner \& Day, 1997). As a result, these employees perceive the supervisor treats them with respect and dignity. Therefore, they feel to increase safety feeling to present their points and concerns.

Accordingly, we formulate the following hypothesis:

Hypothesis 2. Leader-member exchange mediates the relationship between ethical leadership and employee voice behavior.

\subsection{Employee empowerment and employee voice behavior}

According to Conger \& Kanungo, (1988), the concept of empowerment is defined as "a process of enhancing feelings of self-efficacy among organizational members through the identification of conditions that foster powerlessness and through their removal by both formal organizational practices and informal techniques providing efficacy information" (p.474). Besides, (Detert \& Burris, 2007) defined voice as "the discretionary provision of information intended to improve organizational functioning which may challenge and upset the status quo of the organization and its power holders" (p.869). Employee voice is one of the most important characteristics of employee participation. Michael Armstrong (2006) states that there are four specific purposes for employee voice. First, it is to articulate individual dissatisfaction with management or the organization. Second, employee voice serves as an expression of collective organization to management. Third, it contributes to management decision making, particularly regarding work organization, quality, and productivity. Last, employee voice demonstrates the mutuality of the employer-employee relationship.

Leader empowerment behavior can creates environment where encourage employees to express their ideas and enhance the employee's self-efficacy. Study from Gao, Janssen, \& Shi, (2011) indicated that empowering leadership can regulate the relationship between employees' trust on leader and voice behavior. van Dijke, De Cremer, Mayer, \& Van Quaquebeke, (2012) studied the relation between the empowering leadership and 
organizational citizenship behavior. Therefore, we hypothesize:

H3. Leader empowerment behavior has direct positive influences on employees' voice behavior.

\subsection{Employee empowerment as a moderator between leader-member exchange and employee voice behavior}

Many scholars have tested the impact of leader-member exchange and empowerment on employee outcomes through using empirical research such as (Gao et al., 2011; Seibert, Silver, \& Randolph, 2004). Although Harris, Wheeler, \& Kacmar, (2009) examined the significantly impact of leader-member exchange and empowerment on job satisfaction, performance, organizational citizenship behavior and turnover intention, there are few available study that deals with possible consequences, such as employee voice.

How employee experience empowerment from top management affects the relationship between leadermember exchange and employee voice behavior. When employee has empowerment, they may share information and open up line of communication. The trust relationship between leader and employee is increased when employees are permitted to participate in decision-making. Moreover, the relationship between LMX and employee voice behaviors is positive when employees are motivated to express their views. On the other hand, the sharing of information and exchange of resources is likely to be less effective when empowerment is low (Cropanzano \& Mitchell, 2005). Therefore, the relationships between LMX and employee voice behavior are stronger when employees experience a high level of empowerment.

H4. Employee empowerment will moderate the relationship between leader-member exchange and employee voice behavior. The relationship will be stronger for employees higher on empowerment than for those lower on collectivism.

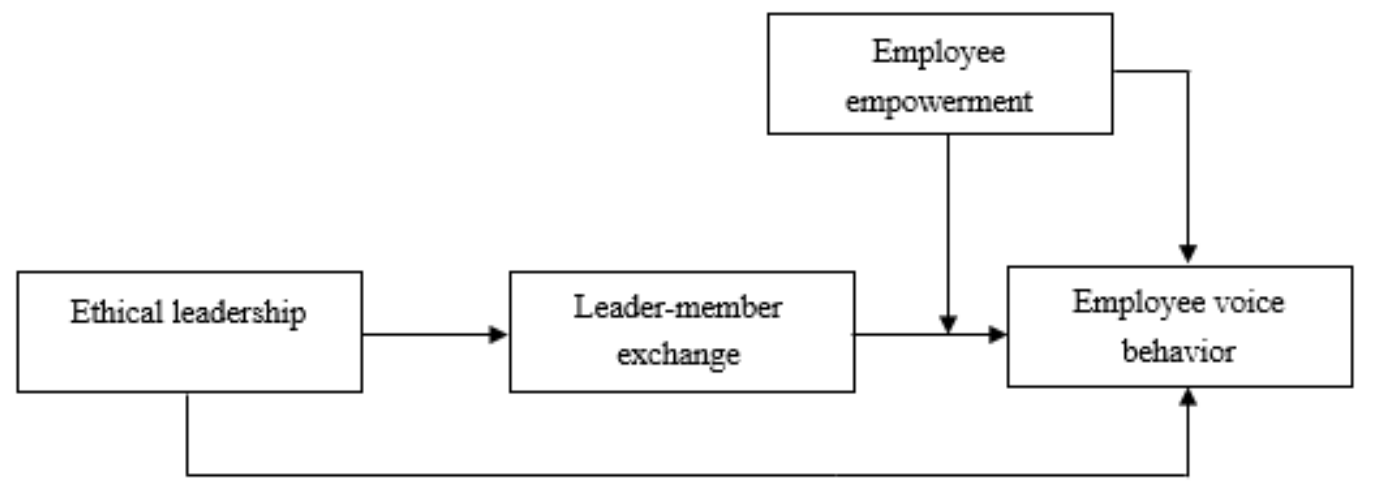

Figure 1. Hypothesized model

\section{Methodology}

\subsection{Participants}

Participants were 718 full time working employees in Vietnamese service companies. The data was collected through convenience sampling. The data was filled by employees so represents subordinate perception. Participants were provided with assurance of confidentiality and anonymity.

Response rate was $47.87 \%$, total questionnaires distributed were 1500 out of which 718 were properly filled and useable. Female comprised $53.8 \%$ of total sample. Respondents ranged in age from 23 to 55 years, with below 25 years $(15.3 \%), 26-35$ years $(44.8 \%), 36-45$ years $(28.4 \%)$, above 46 years $(11.4 \%)$. More than $82 \%$ respondents had completed some college, university degree or post-graduate. Employees ranged in tenure from 0.5 to 14 years, with below 1 year $(16 \%), 1-5$ years $(42.3 \%), 5-10$ years $(30.6 \%)$, and over 10 years $(11 \%)$.

\subsection{Measures}

The measures that were used in this study were chosen for two reasons. Firstly, these measures have consistently strong reliabilities across a number of prior studies. Secondly, they tapped the behavior and attitude that is relevant for the current study.

Ethical leadership was measured on a 10-item scale developed by Brown, Treviño, \& Harrison, (2005c). Sample items include: "listen to what employees have to say". Cronbach's reliability for this scale was 0.897. Leader-member exchange was gauged by the 7-item scale given by (Scandura \& Graen, 1984). Sample items like "I have enough confidence in my leader that I would defend and justify his/her decision if he/she were not present to do so". Cronbach's reliability for this scale was 0.909. Employee empowerment was evaluated by a 4-item scale from (Baird, Su, \& Munir, 2017). It included items like "official channels or norms or rules to guarantee employee participation". Cronbach`s alpha for this was 0.961. Employee voice behavior was measured by a 6item scale given by Van Dyne \& LePine, (1998), and used items like "develops and makes recommendations 
concerning issues that affect this work group". Cronbach`s alpha estimate was 0.855 . All the constructs were evaluated on 5 point Likert scale to reduce the complexities among scales.

\section{Results}

4.1. Confirmatory factor analysis

Table 1 Mean, Standard deviation, Correlation and Reliabilities

\begin{tabular}{|c|c|c|c|c|c|c|c|}
\hline & & Mean & SD & 1 & 2 & 3 & 4 \\
\hline 1 & Ethical leadership & 3.91 & 0.58 & 0.707 & & & \\
\hline 2 & LMX & 3.71 & 0.58 & $.472 * *$ & 0.768 & & \\
\hline 3 & Empowerment & 3.43 & 1.12 & $.314 * *$ & $.185^{* *}$ & 0.929 & \\
\hline 4 & Voice behavior & 3.77 & 0.61 & $.424 * *$ & $.533 * *$ & $.160 * *$ & 0.711 \\
\hline
\end{tabular}

Table 1 represented the correlation and other descriptions. The results show a significant and positive correlation between ethical leadership and leader-member exchange, ethical leadership and employee empowerment, ethical leadership and employee voice behavior, leader-member exchange and employee empowerment, leader-member exchange and employee voice behavior, and employee empowerment and employee voice behavior. Table 2 shows the results of the CFA that surpassed the good fit criteria which in accordance with suggestion of (Bentler \& Bonett, 1980). They suggested $\chi 2 / \mathrm{df}$ should not exceed 3 (in this study $\chi 2 / \mathrm{df}=2.870)$, while estimates for NFI and CFI should be equal or above 0.9 for a good fit $(\mathrm{NFI}=0.928, \mathrm{CFI}=0.952)$. Regarding the estimates for GFI and AGFI, (Scott, Konsynski, Blanning, \& King, 1994) and (Seyal, Rahman, \& Rahim, 2002) suggested estimates above the recommended value of 0.8 as a good fit (GFI $=0.917, A G F I=0.900)$. RMSEA should not exceed 5 for good fit (RMSEA=0.047). Therefore, the hypothesized model provided a suitable fit.

Table 2. Goodness of fit indices

\begin{tabular}{|c|c|c|c|}
\hline \multicolumn{4}{|l|}{ CFA goodness of fit indices } \\
\hline Chi-square & & Absolute Fit measures & \\
\hline Chi-square $\left[\chi^{2}\right]$ & 901.229 & Goodness of fit index [GFI] & 0.917 \\
\hline Degree of freedom $[\mathrm{df}]$ & 314 & Adjusted Goodness of fit index [AGFI] & 0.900 \\
\hline Chi-square/df $\left[\chi^{2} / \mathrm{df}\right]$ & 2.870 & Root mean square of error of & 0.047 \\
\hline Incremental Fit Indices & & approximation [RMSEA] & \\
\hline Normed fit index [NFI] & 0.928 & 90 percent confidence interval for & $(0.040-0.045)$ \\
\hline Comparative fit index [CFI] & 0.952 & RMSEA & 0.027 \\
\hline Relative fit index $[\mathrm{RFI}]$ & 0.919 & Root mean squared residual [RMR] & \\
\hline $\begin{array}{l}\text { Tucker-Lewis Coefficient indices } \\
\text { [TLI] }\end{array}$ & 0.946 & Normed $\chi^{2}$ & \\
\hline
\end{tabular}

We tested the factor loadings, average variance extracted (AVE) and composite reliability (CR) to evaluate the convergent validity of the variables. The results are shown in Table 3. All of the composite reliabilities range from 0.858 to 0.962 ensured the minimum cutoff at 0.60 (Bagozzi \& Yi, 1988), while the estimates for the AVE from 0.500 to 0.863 crossed the threshold of 0.50 (Fornell \& Larcker, 1981). On the other hand, as shown in Table 3 , all the factor loadings were found to be significant at 0.001 level (all above 0.603 ), thus the loadings provided a significant contribution for each construct. Therefore, there was not any issue regarding the convergent validity in the measures. Moreover, cronbach`s alpha were all above 0.70 , representing higher internal consistency and validity of the constructs.

To examine the discriminant validity, the square root of the AVE was compared with the values of correlation between the constructs. Chin, Marcolin, \& Newsted, (2003) suggested that the square root of the AVE of each latent variable from its indicators should exceed that construct's correlation with other constructs. As shown in table 1, the square root of the AVE of each latent construct is greater than that construct's correlation with other constructs.

Additionally, Harman's single-factor test was conducted to check the common method bias. The highest variance explained for all the four constructs was $31.345 \%$, indicating no common method bias in our results (Podsakoff \& Organ, 2016). 
Table 3. Overall reliability of the constructs and factor loadings of indicator

\begin{tabular}{|c|c|c|c|c|c|c|c|}
\hline Constructs & AVE & ASV & MSV & Cronbach $\alpha$ & $\mathrm{CR}$ & $\begin{array}{l}\text { Factor } \\
\text { loadings }\end{array}$ & $\mathrm{T}$ value \\
\hline $\begin{array}{l}\text { 1 Ethical leadership } \\
\text { EL1 } \\
\text { EL2 } \\
\text { EL3 } \\
\text { EL4 } \\
\text { EL5 } \\
\text { EL6 } \\
\text { EL7 } \\
\text { EL8 } \\
\text { EL9 } \\
\text { EL10 }\end{array}$ & 0.500 & & 0.270 & 0.897 & 0.909 & $\begin{array}{l}0.715 \\
0.668 \\
0.696 \\
0.751 \\
0.748 \\
0.709 \\
0.657 \\
0.672 \\
0.690 \\
0.758\end{array}$ & $\begin{array}{l}\text { f.p. } \\
16.173 \\
18.267 \\
18.824 \\
18.839 \\
18.757 \\
15.078 \\
15.796 \\
17.930 \\
16.411\end{array}$ \\
\hline $\begin{array}{l}\text { Leader-Member } \\
\text { exchange } \\
\text { LMX1 } \\
\text { LMX2 } \\
\text { LMX3 } \\
\text { LMX4 } \\
\text { LMX5 } \\
\text { LMX6 } \\
\text { LMX7 }\end{array}$ & 0.589 & & 0.333 & 0.909 & 0.909 & $\begin{array}{l}0.758 \\
0.795 \\
0.791 \\
0.707 \\
0.720 \\
0.788 \\
0.808 \\
\end{array}$ & $\begin{array}{l}\text { f.p. } \\
21.950 \\
21.814 \\
19.206 \\
19.618 \\
21.719 \\
22.333\end{array}$ \\
\hline $\begin{array}{l}\text { Employee } \\
\text { empowerment } \\
\text { EE1 } \\
\text { EE2 } \\
\text { EE3 } \\
\text { EE4 } \\
\end{array}$ & 0.863 & & 0.118 & 0.961 & 0.962 & $\begin{array}{l}0.928 \\
0.946 \\
0.929 \\
0.912 \\
\end{array}$ & $\begin{array}{l}\text { f.p. } \\
46.864 \\
50.236 \\
50.233\end{array}$ \\
\hline $\begin{array}{ll}\text { Employee } & \text { voice } \\
\text { behavior } \\
\text { EVB1 } \\
\text { EVB2 } \\
\text { EVB3 } \\
\text { EVB4 } \\
\text { EVB5 } \\
\text { EVB6 }\end{array}$ & 0.505 & & 0.333 & 0.855 & 0.858 & $\begin{array}{l}0.651 \\
0.804 \\
0.820 \\
0.642 \\
0.715 \\
0.603 \\
\end{array}$ & $\begin{array}{l}\text { f.p. } \\
17.762 \\
18.008 \\
14.856 \\
16.242 \\
14.083 \\
\end{array}$ \\
\hline
\end{tabular}

Note: $A V E=A v e r a g e$ variance extracted; $M S V=$ Maximum shared variance; $A S V=$ Average shared variance; $\mathrm{CR}=$ Composite reliability; f.p. $=$ Fixed parameter

\subsection{Hypothesis testing}

To examine the hypotheses, SPSS version 22 was adopted to conduct a hierarchical regression analysis and the results are represented in Table 4. To execute the examination, the demographic i.e., age, gender, education and tenure were controlled to reduce the impact of it over the employee voice behavior. The results for the main effect (Model 1) of ethical leadership on leader-member exchange $(\mathrm{B}=0.350, \mathrm{p}<0.001)$ revealed a significant and positive connectivity between the two behavioral constructs, supporting H1. Besides, the main effect of employee empowerment on employee voice behavior is non-significant, not supporting H3. For the mediation model (Model $2)$, there existed a positive connection between ethical leadership and employee voice behavior $(B=0.146, p<0.001)$; ethical leadership and leader-member exchange $(B=0.350, p<0.001)$; leader-member exchange and employee voice behavior $(\mathrm{B}=0.215, \mathrm{p}<0.001)$. After entering leader-member exchange as mediator, the effect of ethical leadership on employee voice behavior reduced $(B=0.081, p<0.001)$, which shows that leader-member exchange influenced the relationship between ethical leadership and employee voice behavior as a partial mediator. Thus $\mathrm{H} 2$ is partially supported because ethical leadership influence directly as well as through leader-member exchange (Baron \& Kenny, 1986) (see Fig.1). 
Table 4. Results of hierarchical regression analysis for the hypothesized relationships.

\begin{tabular}{|c|c|c|c|c|c|c|c|c|}
\hline \multirow[t]{3}{*}{$\begin{array}{l}\text { Dependent } \\
\text { Variable } \rightarrow\end{array}$} & \multirow{2}{*}{\multicolumn{2}{|c|}{$\begin{array}{l}\text { Leader-member } \\
\text { exchange } \\
\text { Model } 1 \\
\end{array}$}} & \multicolumn{6}{|c|}{ Employee voice behavior } \\
\hline & & & \multicolumn{4}{|l|}{ Model 2} & \multicolumn{2}{|l|}{ Model 3} \\
\hline & Step 1.1 & Step 1.2 & Step 2.1 & Step 2.2 & Step 2.3 & Step 2.4 & Step 3.1 & Step3.2 \\
\hline $\begin{array}{l}\text { Control variables } \\
\text { Age } \\
\text { Gender } \\
\text { Tenure } \\
\text { Education }\end{array}$ & $\begin{array}{l}0.187^{* * *} \\
0.153^{* * *} \\
0.057 \\
0.258^{* * *}\end{array}$ & $\begin{array}{l}0.149^{* *} \\
0.161^{* * *} \\
0.053 \\
0.132^{* * *}\end{array}$ & $\begin{array}{l}0.336 \\
0.111 \\
0.195 \\
0.339\end{array}$ & $\begin{array}{l}0.321 \\
0.115 \\
0.193 \\
0.287\end{array}$ & $\begin{array}{l}0.293 \\
0.085 \\
0.183 \\
0.262\end{array}$ & $\begin{array}{l}0.296^{* * *} \\
0.078^{*} \\
0.182^{* * *} \\
0.284^{* * *}\end{array}$ & $\begin{array}{l}0.320^{* * *} \\
0.115^{* * *} \\
0.192^{* * *} \\
0.287^{* * *}\end{array}$ & $\begin{array}{l}0.316^{* * *} \\
0.107^{* * *} \\
0.199^{* * *} \\
0.298^{* * *}\end{array}$ \\
\hline $\begin{array}{l}\text { Independent } \\
\text { variable } \\
\text { Ethical leadership } \\
\text { (EL) }\end{array}$ & & $0.350^{* * *}$ & & $0.146^{* * *}$ & 0.081 & & $0.145^{* * *}$ & $0.152^{* * *}$ \\
\hline $\begin{array}{l}\text { Mediator } \\
\text { Leader-member } \\
\text { exchange }\end{array}$ & & & & & $0.185^{* * *}$ & $0.215^{* * *}$ & & \\
\hline $\begin{array}{l}\text { Moderator } \\
\text { Employee } \\
\text { empowerment (EE) }\end{array}$ & & & & & & & 0.004 & -0.003 \\
\hline $\begin{array}{l}\text { Interaction } \\
\mathrm{EL}^{*} \mathrm{EE}\end{array}$ & & & & & & & & $0.114^{* * *}$ \\
\hline F-value & $54.312^{* * *}$ & $106.332^{* * *}$ & $277.263^{* * *}$ & $33.024^{* * *}$ & $46.183^{* * *}$ & $257.778^{* * *}$ & $16.505^{* * *}$ & $25.198^{* * *}$ \\
\hline $\mathrm{R}^{2}$ & 0.234 & 0.333 & 0.609 & 0.626 & 0.649 & 0.644 & 0.626 & 0.639 \\
\hline Adjusted $\mathrm{R}^{2}$ & 0.229 & 0.328 & 0.606 & 0.623 & 0.646 & 0.642 & 0.623 & 0.635 \\
\hline Change $\mathrm{R}^{2}$ & 0.234 & 0.100 & 0.609 & 0.017 & 0.023 & 0.035 & 0.017 & 0.013 \\
\hline
\end{tabular}

For testing the moderation effects, we used a technique that suggested by Muller, Judd, \& Yzerbyt, (2005).

First, the control variables were regressed toward the outcome then leader-member exchange and employee empowerment (Model 3). Last, the standardized values of interaction terms (leader-member exchange*employee empowerment) were regressed toward the employee voice behavior along and controlled for the demographic variables. The significant and positive result indicated that employee empowerment strengthens the positive relation between leader-member exchange and employee voice behavior $(B=0.114, p<0.001)$. Therefore, $H 4$ stands true as shown in Fig.2, underlining that as employee empowerment increases, leader-member exchange plays a stronger role toward stimulating employee voice behavior. The significant estimates for $\mathrm{R}^{2}$ revealed an additional impact of ethical leadership, leader-member exchange and employee empowerment over the ultimate outcome (employee voice behavior).

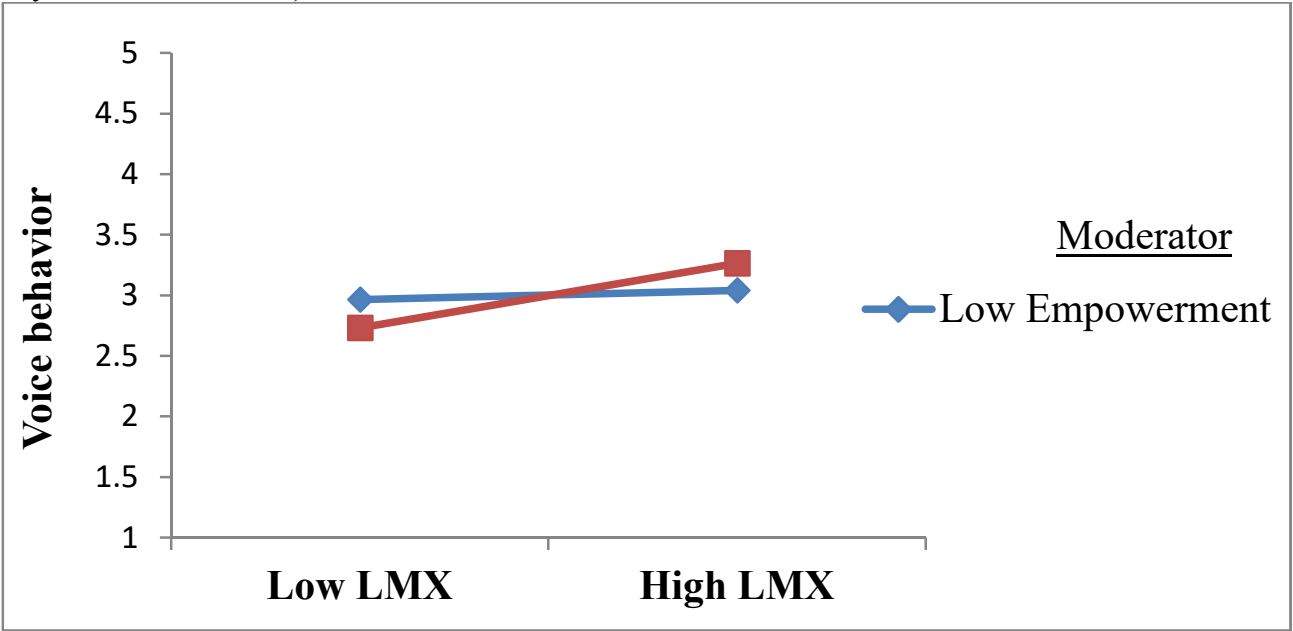

Figure 2. Moderating effect of employee empowerment on the relationship between leader-member exchange and employee voice behavior.

\section{Discussion}

This paper concludes ethical leadership behavior influence employee voice behavior through leader-member exchange; employee empowerment has moderating effect between leader-member exchange and employee voice 
behavior.

Firstly, ethical leadership behavior can create an environment where followers may have a greater sense of responsibility, autonomy, more information and feedback. In particular, ethical leadership behavior provides positive feedback, encourage followers to express their ideas, develop staff skills.

Secondly, leader-member exchange refers to the individuals' belief in persistence to resolve problem when facing difficulty, it motivates employee behavior. High leader-member exchange will produce enough confidence which strengthen employee voice; conversely, low leader-member exchange may cause less employee voice.

Employee empowerment may produce a trust between the leader and follower, which strengthen the employee voice behavior. Employee will consider the empowerment as an information of their excellent capacity, and then more likely to express advice to obtain leader`s further trust.

\section{Limitation and future research direction}

The current study was conducted on basic of convenience sampling later researches can include probability sampling. The data was mainly collected from service sector of Vietnam. In the future, other sectors can be used to check whether sector wise variance in the results exists or does not effect as such. The questionnaires were filled by employees because they represent subordinates perception. In future it is possible that employee voice behavior can be rated by immediate supervisors in order to avoid common method bias. On the other hand, the employees considered in this study belonged to service companies in Vietnam. Therefore, the presented findings may not be conformity with other organizational context. Thus, future researches may be considered collecting the data from different sectors to generalize the findings of this study.

\section{References}

Bagozzi, R. P., \& Yi, Y. (1988). On the evaluation of structural equation models. Journal of the Academy of Marketing Science, 16(1), 74-94. https://doi.org/10.1007/BF02723327

Baird, K., Su, S., \& Munir, R. (2017). The relationship between the enabling use of controls, employee empowerment, and performance. Personnel Review, 47(1), 257-274. https://doi.org/10.1108/PR-12-20160324

Bandura, A., \& Walters, R. H. (1977). Social learning theory (Vol. 1). Prentice-hall Englewood Cliffs, NJ.

Baron, R. M., \& Kenny, D. A. (1986). The moderator-mediator variable distinction in social psychological research: conceptual, strategic, and statistical considerations. Journal of Personality and Social Psychology, 51(6), 1173-1182.

Bentler, P. M., \& Bonett, D. G. (1980). Significance tests and goodness of fit in the analysis of covariance structures. Psychological Bulletin, 88(3), 588-606. https://doi.org/10.1037/0033-2909.88.3.588

Blau, P. M. (1964). Exchange and Power in Social Life. Transaction Publishers.

Brown, M. E., \& Treviño, L. K. (2006). Ethical leadership: A review and future directions. The Leadership Quarterly, 17(6), 595-616. https://doi.org/10.1016/j.leaqua.2006.10.004

Brown, M. E., Treviño, L. K., \& Harrison, D. A. (2005a). Ethical leadership: A social learning perspective for construct development and testing. Organizational Behavior and Human Decision Processes, 97(2), 117134. https://doi.org/10.1016/j.obhdp.2005.03.002

Brown, M. E., Treviño, L. K., \& Harrison, D. A. (2005b). Ethical leadership: A social learning perspective for construct development and testing. Organizational Behavior and Human Decision Processes, 97(2), 117134.

Brown, M. E., Treviño, L. K., \& Harrison, D. A. (2005c). Ethical leadership: A social learning perspective for construct development and testing. Organizational Behavior and Human Decision Processes, 97(2), 117134. https://doi.org/10.1016/j.obhdp.2005.03.002

Chin, W. W., Marcolin, B. L., \& Newsted, P. R. (2003). A Partial Least Squares Latent Variable Modeling Approach for Measuring Interaction Effects: Results from a Monte Carlo Simulation Study and an ElectronicMail Emotion/Adoption Study. Information Systems Research, 14(2), 189-217. https://doi.org/10.1287/isre.14.2.189.16018

Conger, J. A., \& Kanungo, R. N. (1988). The empowerment process: Integrating theory and practice. Academy of Management Review, 13(3), 471-482.

Cropanzano, R., \& Mitchell, M. S. (2005). Social exchange theory: An interdisciplinary review. Journal of Management, 31(6), 874-900.

Detert, J. R., \& Burris, E. R. (2007). Leadership behavior and employee voice: Is the door really open? Academy of Management Journal, 50(4), 869-884.

Fornell, C., \& Larcker, D. F. (1981). Evaluating Structural Equation Models with Unobservable Variables and Measurement Error. Journal of Marketing Research, 18(1), 39-50. https://doi.org/10.2307/3151312

Gao, L., Janssen, O., \& Shi, K. (2011). Leader trust and employee voice: The moderating role of empowering leader behaviors. The Leadership Quarterly, 22(4), 787-798. 
Gerstner, C. R., \& Day, D. V. (1997). Meta-Analytic review of leader-member exchange theory: Correlates and construct issues. Journal of Applied Psychology, 82(6), 827.

Graen, G. B., \& Scandura, T. A. (1987). Toward a psychology of dyadic organizing. Research in Organizational Behavior.

Harris, K. J., Wheeler, A. R., \& Kacmar, K. M. (2009). Leader-member exchange and empowerment: Direct and interactive effects on job satisfaction, turnover intentions, and performance. The Leadership Quarterly, 20(3), $371-382$.

Hassan, S., Mahsud, R., Yukl, G., \& Prussia, G. E. (2013). Ethical and empowering leadership and leader $\begin{array}{lllll}\text { effectiveness. Journal of } & \text { Managerial }\end{array}$ https://doi.org/10.1108/02683941311300252

Hirschman, A. O. (1970). Exit, voice, and loyalty: Responses to decline in firms, organizations, and states (Vol. 25). Harvard university press.

Muller, D., Judd, C. M., \& Yzerbyt, V. Y. (2005). When moderation is mediated and mediation is moderated. Journal of Personality and Social Psychology, 89(6), 852-863. https://doi.org/10.1037/0022-3514.89.6.852

Nahrgang, J. D., Morgeson, F. P., \& Ilies, R. (2009). The development of leader-member exchanges: Exploring how personality and performance influence leader and member relationships over time. Organizational Behavior and Human Decision Processes, 108(2), 256-266.

Piccolo Ronald F., Greenbaum Rebecca, Hartog Deanne N. den, \& Folger Robert. (2010). The relationship between ethical leadership and core job characteristics. Journal of Organizational Behavior, 31(2-3), 259278. https://doi.org/10.1002/job.627

Podsakoff, P. M., \& Organ, D. W. (2016). Self-Reports in Organizational Research: Problems and Prospects: Journal of Management. https://doi.org/10.1177/014920638601200408

Scandura, T. A., \& Graen, G. B. (1984). Moderating effects of initial leader-member exchange status on the effects of a leadership intervention. Journal of Applied Psychology, 69(3), 428-436. https://doi.org/10.1037/00219010.69.3.428

Scott, J., Konsynski, B., Blanning, R., \& King, D. (1994). The Measurement of Information Systems Effectiveness: Evaluating a Measuring Instrument. Retrieved from https://works.bepress.com/benn/20/

Seibert, S. E., Silver, S. R., \& Randolph, W. A. (2004). Taking empowerment to the next level: A multiple-level model of empowerment, performance, and satisfaction. Academy of Management Journal, 47(3), 332-349.

Seyal, A. H., Rahman, M. N. A., \& Rahim, M. M. (2002). Determinants of academic use of the Internet: A structural equation model. Behaviour \& Information Technology, 21(1), 71-86. https://doi.org/10.1080/01449290210123354

Thibaut, J. W., \& Walker, L. (1975). Procedural justice: A psychological analysis. L. Erlbaum Associates.

van Dijke, M., De Cremer, D., Mayer, D. M., \& Van Quaquebeke, N. (2012). When does procedural fairness promote organizational citizenship behavior? Integrating empowering leadership types in relational justice models. Organizational Behavior and Human Decision Processes, 117(2), 235-248.

Van Dyne, L., \& LePine, J. A. (1998). Helping and Voice Extra-Role Behaviors: Evidence of Construct and Predictive Validity. The Academy of Management Journal, 41(1), 108-119. https://doi.org/10.2307/256902

Walumbwa, F. O., Mayer, D. M., Wang, P., Wang, H., Workman, K., \& Christensen, A. L. (2011). Linking ethical leadership to employee performance: The roles of leader-member exchange, self-efficacy, and organizational identification. Organizational Behavior and Human Decision Processes, 115(2), $204-213$. https://doi.org/10.1016/j.obhdp.2010.11.002 